\title{
Environmental influence on the choice of medicinal animals: a case study from northeastern Brazil
}

\author{
lamara da Silva Policarpo Brito ${ }^{1,2^{*}}$ D, Anna Karolina Martins Borges ${ }^{1,2}$, Sérgio de Faria Lopes ${ }^{2}$, \\ Thelma Lúcia Pereira Dias ${ }^{1,2}$ and Rômulo Romeu Nóbrega Alves ${ }^{1,2}$
}

\begin{abstract}
Background: Animals from various taxonomic groups are commonly used in folk medicine, and their selection seems to be directly linked to their availability and accessibility. In the present study, we analyzed the use of animals as a source of folk medicines in a community in northeastern Brazil with access to aquatic and terrestrial animals. We hypothesize that the medicinal fauna is well represented by species of both habitat types.

Methods: For the collection of information, semi-structured questionnaires were applied to local residents.

Results: We recorded the use of 22 animals used as medicinal resources in the community, distributed among eight taxonomic categories, which are used to treat 38 types of diseases. Of the therapeutic animals, 14 species are terrestrial and 8 species can be considered aquatic occurring in marine or estuarine habitats.

Conclusions: Our data confirm the tendency of human communities to use affordable medicinal animals in local ecosystems. We also found that medicinal use represents a strategy of optimizing the use of resources and is related to the economic, historical, social, cultural, and ecological contexts in which the community is inserted.
\end{abstract}

Keywords: Folk medicine, Zootherapy, Medicinal animals

\section{Background}

Medicinal plants and animals have been used in virtually all cultures as a source of medicine [1-5]. Due to the extensive use of plant materials [6-10], traditional medicine is associated with herbalism. However, recent research on animal species used in folk medicinal practices worldwide shows that products derived from medicinal animals are used directly in the elaboration of natural remedies that are widely sought in folk medicinal practices [11-16] and involve a large number of species. For example, at least 1500 animal species have some medicinal use in folk Chinese medicine [17] and in Latin America, at least 584 species have been reported to be used in folk medicinal practices [18]. Worldwide, at least

\footnotetext{
* Correspondence: iamarasp@gmail.com

${ }^{1}$ Programa de Pos-Graduacao em Ciências Biológicas (Zoologia),

Departamento de Sistemática e Ecologia da Universidade Federal da Paraíba,

João Pessoa, PB 58051-900, Brazil

${ }^{2}$ Departamento de Biologia, Universidade Estadual da Paraíba, Av. das

Baraúnas, 351/Campus, Universitário, Bodocongó, Campina Grande, PB 58109-753, Brazil
}

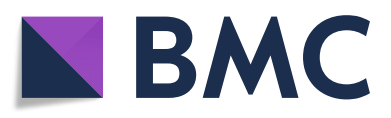

(c) The Author(s). 2019 Open Access This article is distributed under the terms of the Creative Commons Attribution 4.0 International License (http://creativecommons.org/licenses/by/4.0/), which permits unrestricted use, distribution, and

reproduction in any medium, provided you give appropriate credit to the original author(s) and the source, provide a link to the Creative Commons license, and indicate if changes were made. The Creative Commons Public Domain Dedication waiver (http://creativecommons.org/publicdomain/zero/1.0/) applies to the data made available in this article, unless otherwise stated.
108 mammalian carnivores [21], 266 marine invertebrates [11], and hundreds of terrestrial invertebrates are used in folk remedies [22].

Although the use of animals for medicinal purposes is widespread and important in several aspects (e.g., cultural, economic, social, and ecological), the subject has been insufficiently researched when compared with medicinal plants [23]. Nevertheless, in the last 20 years, studies investigating the importance of animal use in folk medicine have become more frequent worldwide [12, 24-28] supporting the belief that animal use is widespread and present in the most diverse folk medical systems in the world [12].

In Brazil, a country with significant biological and cultural richness, many medicinal animals have been registered in several localities [29-31], especially in coastal communities $[23,32,33]$ and in the semiarid region [34, 35]. These studies reveal that there is a tendency to select local species for use in folk medicine. Thus, people 
living in coastal areas tend to use mostly aquatic/marine resources while people from arid zones tend to use more animals and less aquatic resources [23, 33, 34, 36]. This situation is similar to that observed in the selection of plant species used by human communities, whose choice is influenced by their availability and accessibility [37].

Given the above, the aim of this article was to analyze the use of animals in medicinal practices of a fishing community in the district of Diogo Lopes, municipality of Macau, Rio Grande do Norte, Brazil. This fishing community is located in a peculiar region, where the dry forest extends to the coast. Therefore, the community has direct access to the animal resources that occur in a semiarid environment and the available fishing resources in the estuary and marine environment. Thus, the medicinal fauna used by the local population is expected to come from both the coastal area and the dry forest environments, since the diversity of environments enables the availability and access to a range of terrestrial and aquatic animals.

\section{Methods}

\section{Study area}

Diogo Lopes district is part of the municipality of Macau, located approximately $185 \mathrm{~km}$ from the state capital of Rio Grande do Norte, Natal, Brazil (Fig. 1). The main access is through the road BR-406 and it covers an area of $100 \mathrm{~km}^{2}$ (Santos 2003). Data from the area is based on the Macao Meteorological Station, with latitude $5^{\circ} 07^{\prime} \mathrm{S}$, longitude $36^{\circ} 38^{\prime} \mathrm{W}$, and altitude of six meters [38]. According to ECOPLAM [39], the district of Diogo Lopes has a warm semiarid climate and terrestrial ecosystems are classified as dry forest, dune fields, and saline environments. The population is formed mostly by fishermen. Both the adult male and female populations live on the banks of the estuary where they benefit from fishing resources that are common to the region [40].

\section{Data collection}

The execution of this research was reviewed and approved by the Research Ethics Committee of the Health Sciences Center of the Federal University of Paraíba (No. $2,244,394)$. Data collection was performed in the first semester of 2018. However, prior to the data collection, a presentation and clarification on the objectives of the research were given, and permission was granted by the interviewees to record the information obtained.

Information on the use of animals for medicinal purposes was obtained through semi-structured questionnaires, complemented by free interviews and informal conversations [41]. Additionally, during the interviews, the snowball technique was applied, which according to Baldin and Munhoz [42] is a non-probabilistic sample form used in social research in which the participants of a study indicate new participants who also indicate new participants and so on. Ninety-five people were interviewed, 50 females and 45 males. All individuals

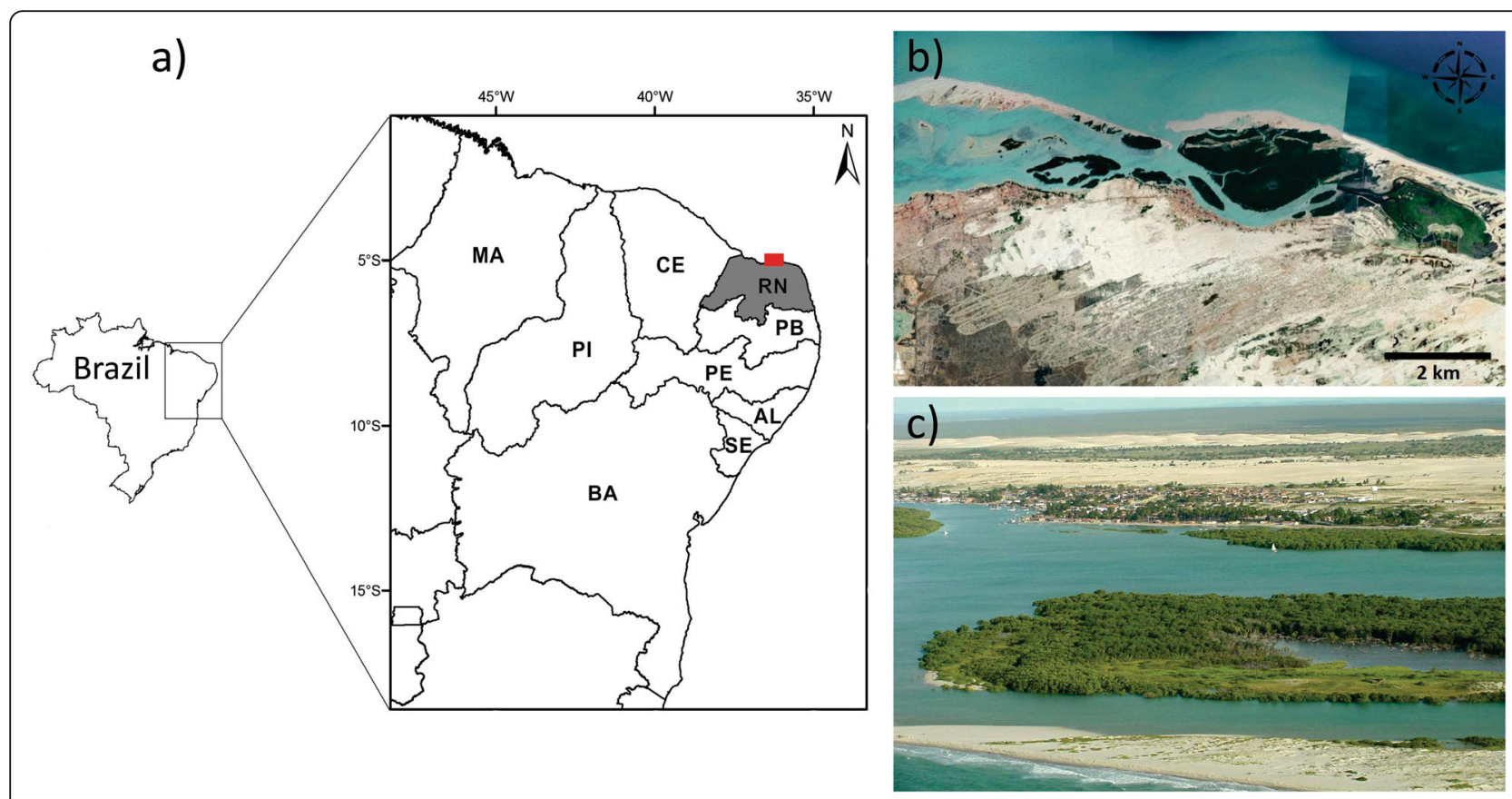

Fig. 1 a Map of surveyed area, State of Rio Grande do Norte, northeast coast of Brazil. b Satellite image showing the coastal ecosystems and c partial view of the mangroves. Images: b Google Earth, c Getúlio Moura 
interviewed claimed to have used animals as a medicinal resource at some point in their lives.

The interviews were conducted individually, and the questionnaires contained questions about the name of the animal used for medicinal purposes, the parts used, diseases treated, ways of preparation and use, limitations of use, adverse effects, ways of obtaining the animal, efficacy of the medicine, preference between the zootherapic or synthetic, and indications of people who were also using zootherapy.

Vernacular names of species were recorded as cited by informants, and animals were identified as follows: (1) analysis of specimens donated by informants; (2) analysis of photographs of the animals (or their parts) taken during the interviews; (3) through the vernacular names, with the help of taxonomists familiar with the fauna of the study area. In the case of animals whose identification was not possible using the methods previously described, a specimen was collected for later identification.

The conservation status of these species was assessed through the Red List of Threatened Species of the International Union for the Conservation of Nature and Natural Resources (IUCN) [43] and the List of Brazilian Endangered Species [44].

\section{Data analysis}

Initially, the data obtained from the interviews were organized into spreadsheets. In addition, all diseases treated by the abovementioned zootherapeutic drugs were grouped into 10 categories, based on the classification used by the Brazilian Center for Disease Classification (1993) as follows: (1) respiratory tract diseases (RTD); (2) digestive tract diseases; (3) undefined diseases; (4) external causes of morbidity and mortality; (5) diseases of the musculoskeletal system and connective tissue; (6) injuries, poisoning and some other consequences of external causes; (7) diseases of the circulatory system; (8) skin and subcutaneous tissue diseases; (9) nervous system diseases; and (10) ear and mastoid apophysis disorders (Table 1).

\section{Relative importance}

In order to assess which species are of greatest cultural importance to informants, the relative importance (RI) of the species (adapted from Bennett and Prance [45]) was calculated. The value is obtained by the formula: RI $=\mathrm{NBS}+\mathrm{NP}$, where NBS = number of body systems (disease categories), which is given by the number of body systems treated by a particular species (NBSS) over the total number of body systems treated by the most versatile species $(\mathrm{NBS}=\mathrm{NBSS} / \mathrm{NBSVS})$, and $\mathrm{NP}=$ number of properties, which is given by the number of properties assigned to a given species (NPS) over the total number of properties assigned to the most versatile species (NPVS) NP = NPS/NPVS.

\section{Results and discussion}

The use of 22 animals as a medicinal resource was recorded from the informants (Table 2). Of this total, 19 are vertebrates and three invertebrates, distributed in eight taxonomic categories, of which mammals $(n=6$ species), reptiles $(n=6)$, and fish $(n=4)$ were the most important. It is not surprising, given that vertebrates are the most commonly used animals in Brazilian folk medicine [29]. The prominence of the recorded taxonomic categories in the surveyed area has also been recorded in several studies, demonstrating their relevance as a therapeutic resource [23, 33, 36, 46-53].

The most cited species by the individuals interviewed were Salvator merianae (Duméril and Bibron, 1839)teju (55 citations), Ovis aries (Linnaeus, 1758)-sheep (24 citations), Chelonia mydas (Linnaeus, 1758)_green

Table 1 Categories of diseases treated with zootherapeutic resources in the surveyed communities, according to CBCD - Brazilian Center for Classification of Diseases (1993)

\begin{tabular}{|c|c|c|}
\hline Categories & Diseases & Total \\
\hline Musculoskeletal and connective tissue disorders & $\begin{array}{l}\text { Leg pain, plantar fasciitis, "hard nerves," bone pain, joint pain, knee pain, hardened joints, } \\
\text { spine pain, rheumatism, crooked knee }\end{array}$ & 10 \\
\hline Respiratory tract diseases & Sore throat, flu, cough, throat inflammation, asthma, asthma crisis & 7 \\
\hline Undefined diseases & Chest lump, inflammation, cracked heels, itching, healing & 5 \\
\hline External causes of morbidity and mortality & Swelling, wound, barbs, thorn removal & 4 \\
\hline $\begin{array}{l}\text { Injury, poisoning, and some other consequences } \\
\text { of external causes }\end{array}$ & Bruise, arm dislocation, ankle fracture & 3 \\
\hline Diseases of the circulatory system & Hemorrhoids, stroke, thrombosis & 3 \\
\hline Skin and subcutaneous tissue disorders & Boil, blackhead, acne & 3 \\
\hline Nervous system disorders & Headache & 1 \\
\hline Ear and mastoid apophysis disorders & Ear pain & 1 \\
\hline Digestive tract diseases & Constipation & 1 \\
\hline
\end{tabular}


Table 2 Zootherapies used in the fishing community of Diogo Lopes, Macau - RN

\begin{tabular}{|c|c|c|c|c|c|c|c|}
\hline $\begin{array}{l}\text { Class/family/species/ } \\
\text { "local name," popular } \\
\text { name (En/US) }\end{array}$ & $\begin{array}{l}\text { Number } \\
\text { of } \\
\text { citations }\end{array}$ & $\begin{array}{l}\text { Parts } \\
\text { used }\end{array}$ & Diseases & Disease categories & $\begin{array}{l}\text { IUCN } \\
(2018)\end{array}$ & CITES & $\begin{array}{l}\text { Brazilian } \\
\text { list MMA } \\
(2014)\end{array}$ \\
\hline \multicolumn{8}{|l|}{ Mammalia } \\
\hline \multicolumn{8}{|l|}{ Bovidae } \\
\hline $\begin{array}{l}\text { Ovis aries Linnaeus, } \\
\text { 1758-"carneiro," } \\
\text { sheep }\end{array}$ & 24 & $\begin{array}{l}\text { Fat, } \\
\text { suet }\end{array}$ & $\begin{array}{l}\text { Bruise, arm dislocation, ankle fracture, } \\
\text { leg pain, swelling, plantar fasciitis, } \\
\text { "hard nerves," joint pain, knee pain, } \\
\text { bone pain, hardened joints, crooked } \\
\text { knee, cracked heels }\end{array}$ & $\begin{array}{l}\text { Injury, poisoning and some other } \\
\text { consequences of external causes, } \\
\text { musculoskeletal and connective } \\
\text { tissue disorders, undefined diseases }\end{array}$ & 0 & 0 & 0 \\
\hline \multicolumn{8}{|l|}{ Canidae } \\
\hline $\begin{array}{l}\text { Canis familiaris } \\
\text { Linnaeus, 1758- } \\
\text { "cachorro," dog }\end{array}$ & 1 & Feces & Throat inflammation & Respiratory tract diseases & 0 & 0 & 0 \\
\hline $\begin{array}{l}\text { Cerdocyon thous } \\
\text { (Linnaeus, 1766)- } \\
\text { "raposa," crab- } \\
\text { eating fox }\end{array}$ & 15 & $\begin{array}{l}\text { Fat, } \\
\text { leather }\end{array}$ & $\begin{array}{l}\text { Sore throat, throat inflammation, } \\
\text { hemorrhoids, inflammation }\end{array}$ & $\begin{array}{l}\text { Respiratory tract diseases, diseases of } \\
\text { the circulatory system, undefined } \\
\text { diseases }\end{array}$ & LC & $\|$ & 0 \\
\hline \multicolumn{8}{|l|}{ Cervidae } \\
\hline $\begin{array}{l}\text { Mazama sp.- } \\
\text { "veado," deer }\end{array}$ & 1 & Fat & Leg pain & $\begin{array}{l}\text { Musculoskeletal and connective } \\
\text { tissue disorders }\end{array}$ & 0 & 0 & 0 \\
\hline \multicolumn{8}{|l|}{ Dasypodidae } \\
\hline $\begin{array}{l}\text { Euphractus } \\
\text { sexcinctus } \\
\text { (Linnaeus, 1758)- } \\
\text { "tatu-peba," six- } \\
\text { banded armadillo }\end{array}$ & 2 & Fat & Thorn removal, ear pain & $\begin{array}{l}\text { External causes of morbidity and } \\
\text { mortality, ear and mastoid apophysis } \\
\text { disorders }\end{array}$ & LC & 0 & 0 \\
\hline \multicolumn{8}{|l|}{ Delphinidae } \\
\hline $\begin{array}{l}\text { Sotalia guianensis } \\
\text { (P.-J. van Bénéden, } \\
\text { 1864)_-"boto- } \\
\text { cinza," Guiana } \\
\text { dolphin }\end{array}$ & 4 & Fat & $\begin{array}{l}\text { Itching, throat inflammation, leg pain, } \\
\text { "hard nerves" }\end{array}$ & $\begin{array}{l}\text { Undefined diseases, respiratory tract } \\
\text { diseases, musculoskeletal and } \\
\text { connective tissue disorders }\end{array}$ & DD & 0 & VU \\
\hline \multicolumn{8}{|l|}{ Birds } \\
\hline \multicolumn{8}{|l|}{ Cathartidae } \\
\hline $\begin{array}{l}\text { Coragyps atratus } \\
\text { (Bechstein, 1793)- } \\
\text { "urubu-de-cabeça- } \\
\text { preta," American } \\
\text { black vulture }\end{array}$ & 1 & Liver & Asthma & Respiratory tract diseases & LC & 0 & 0 \\
\hline \multicolumn{8}{|l|}{ Phasianidae } \\
\hline $\begin{array}{l}\text { Gallus gallus } \\
\text { (Linnaeus, 1758)- } \\
\text { "galo," chicken }\end{array}$ & 11 & Fat & $\begin{array}{l}\text { Sore throat, throat inflammation, boil, } \\
\text { chest lump, inflammation, constipation }\end{array}$ & $\begin{array}{l}\text { Respiratory tract diseases, skin and } \\
\text { subcutaneous tissue disorders, } \\
\text { undefined diseases, digestive tract } \\
\text { diseases }\end{array}$ & LC & 0 & 0 \\
\hline \multicolumn{8}{|l|}{ Reptilia } \\
\hline \multicolumn{8}{|l|}{ Boidae } \\
\hline $\begin{array}{l}\text { Boa constrictor } \\
\text { Linnaeus, 1758- } \\
\text { "jiboia," boa }\end{array}$ & 2 & Fat, oil & Ear pain, spine pain & $\begin{array}{l}\text { Ear and mastoid apophysis disorders, } \\
\text { musculoskeletal and connective } \\
\text { tissue disorders }\end{array}$ & 0 & 0 & 0 \\
\hline \multicolumn{8}{|l|}{ Cheloniidae } \\
\hline $\begin{array}{l}\text { Chelonia mydas } \\
\text { (Linnaeus, 1758)_- } \\
\text { "tartaruga-verde," } \\
\text { green turtle }\end{array}$ & 17 & Fat, oil & $\begin{array}{l}\text { Throat inflammation, bone pain, spine } \\
\text { pain, rheumatism, stroke, thrombosis, } \\
\text { boil, healing }\end{array}$ & $\begin{array}{l}\text { Respiratory tract diseases, } \\
\text { musculoskeletal and connective } \\
\text { tissue disorders, diseases of the } \\
\text { circulatory system, skin and } \\
\text { subcutaneous tissue disorders, } \\
\text { undefined diseases }\end{array}$ & EN & 0 & VU \\
\hline
\end{tabular}


Table 2 Zootherapies used in the fishing community of Diogo Lopes, Macau - RN (Continued)

\begin{tabular}{|c|c|c|c|c|c|c|c|}
\hline $\begin{array}{l}\text { Class/family/species/ } \\
\text { "local name," popular } \\
\text { name (En/US) }\end{array}$ & $\begin{array}{l}\text { Number } \\
\text { of } \\
\text { citations }\end{array}$ & $\begin{array}{l}\text { Parts } \\
\text { used }\end{array}$ & Diseases & Disease categories & $\begin{array}{l}\text { IUCN } \\
(2018)\end{array}$ & CITES & $\begin{array}{l}\text { Brazilian } \\
\text { list MMA } \\
(2014)\end{array}$ \\
\hline \multicolumn{8}{|l|}{ Iguanidae } \\
\hline $\begin{array}{l}\text { Iguana iguana } \\
\text { (Linnaeus, 1758)_- } \\
\text { "Camaleão," } \\
\text { common green } \\
\text { iguana }\end{array}$ & 9 & $\begin{array}{l}\text { Fat, } \\
\text { bones }\end{array}$ & $\begin{array}{l}\text { Sore throat, throat inflammation, } \\
\text { barbs, hemorrhoids }\end{array}$ & $\begin{array}{l}\text { Respiratory tract diseases, external } \\
\text { causes of morbidity and mortality, } \\
\text { diseases of the circulatory system }\end{array}$ & 0 & 0 & 0 \\
\hline \multicolumn{8}{|l|}{ Teiidae } \\
\hline $\begin{array}{l}\text { Salvator merianae } \\
\text { (Duméril \& Bibron, } \\
\text { 1839)_-lagarto } \\
\text { teju," tegu lizard }\end{array}$ & 55 & Fat & $\begin{array}{l}\text { Sore throat, throat inflammation, } \\
\text { wound, ear pain, knee pain }\end{array}$ & $\begin{array}{l}\text { Respiratory tract diseases, external } \\
\text { causes of morbidity and mortality, } \\
\text { ear and mastoid apophysis } \\
\text { disorders, musculoskeletal and } \\
\text { connective tissue disorders }\end{array}$ & LC & 0 & 0 \\
\hline \multicolumn{8}{|l|}{ Tropiduridae } \\
\hline $\begin{array}{l}\text { Tropidurus hispidus } \\
\text { (Spix, 1825)- } \\
\text { "lagartixa de } \\
\text { lajedo," Peters' lava } \\
\text { lizard }\end{array}$ & 4 & $\begin{array}{l}\text { Meat, } \\
\text { blood, } \\
\text { head }\end{array}$ & Sore throat, throat inflammation & Respiratory tract diseases & 0 & 0 & 0 \\
\hline \multicolumn{8}{|l|}{ Viperidae } \\
\hline $\begin{array}{l}\text { Crotalus durissus } \\
\text { Linnaeus, 1758-- } \\
\text { "cascavel," South } \\
\text { American } \\
\text { rattlesnake }\end{array}$ & 6 & Fat, oil & $\begin{array}{l}\text { Hardened joints, bone pain, spine } \\
\text { pain, blackhead, acne, cracked heels, } \\
\text { headache }\end{array}$ & $\begin{array}{l}\text { Musculoskeletal and connective } \\
\text { tissue disorders, skin and } \\
\text { subcutaneous tissue disorders, } \\
\text { nervous system disorders }\end{array}$ & LC & III & 0 \\
\hline \multicolumn{8}{|l|}{ Amphibia } \\
\hline \multicolumn{8}{|l|}{ Bufonidae } \\
\hline $\begin{array}{l}\text { Rhinella jimi } \\
\text { (Stevaux, 2002)- } \\
\text { "sapo cururu," frog }\end{array}$ & 1 & Fat & Throat inflammation & Respiratory tract diseases & LC & 0 & 0 \\
\hline \multicolumn{8}{|l|}{ Elasmobranchii } \\
\hline \multicolumn{8}{|l|}{ Carcharhinidae } \\
\hline $\begin{array}{l}\text { Rhizoprionodon } \\
\text { lalandii (Müller \& } \\
\text { Henle, 1839)—- } \\
\text { "tubarão," Brazilian } \\
\text { sharpnose shark }\end{array}$ & 2 & $\begin{array}{l}\text { Liver } \\
\text { oil }\end{array}$ & Stroke, healing & $\begin{array}{l}\text { Diseases of the circulatory system, } \\
\text { undefined diseases }\end{array}$ & DD & 0 & 0 \\
\hline \multicolumn{8}{|l|}{ Actinopterygii } \\
\hline \multicolumn{8}{|l|}{ Echeneidae } \\
\hline $\begin{array}{l}\text { Echeneis naucrates } \\
\text { Linnaeus, 1758- } \\
\text { "rêmora," whitefin } \\
\text { sharksucker }\end{array}$ & 1 & $\begin{array}{l}\text { Sucker/ } \\
\text { fixer } \\
\text { part }\end{array}$ & Asthma crisis & Respiratory tract diseases & LC & 0 & 0 \\
\hline \multicolumn{8}{|l|}{ Scombridae } \\
\hline $\begin{array}{l}\text { Scomberomorus } \\
\text { cavalla (Cuvier, } \\
\text { 1829)_-"cavala," } \\
\text { king mackerel }\end{array}$ & 1 & Posts & Asthma crisis & Respiratory tract diseases & LC & 0 & 0 \\
\hline \multicolumn{8}{|l|}{ Syngnathidae } \\
\hline $\begin{array}{l}\text { Hippocampus reidi } \\
\text { Ginsburg, 1933-- } \\
\text { "cavalo-marinho," } \\
\text { Long-snout } \\
\text { Seahorse }\end{array}$ & 1 & $\begin{array}{l}\text { Whole } \\
\text { body }\end{array}$ & Asthma crisis & Respiratory tract diseases & NT & 0 & VU \\
\hline
\end{tabular}


Table 2 Zootherapies used in the fishing community of Diogo Lopes, Macau - RN (Continued)

\begin{tabular}{|c|c|c|c|c|c|c|c|}
\hline $\begin{array}{l}\text { Class/family/species/ } \\
\text { "local name," popular } \\
\text { name (En/US) }\end{array}$ & $\begin{array}{l}\text { Number } \\
\text { of } \\
\text { citations }\end{array}$ & $\begin{array}{l}\text { Parts } \\
\text { used }\end{array}$ & Diseases & Disease categories & $\begin{array}{l}\text { IUCN } \\
(2018)\end{array}$ & CITES & $\begin{array}{l}\text { Brazilian } \\
\text { list MMA } \\
(2014) \\
\end{array}$ \\
\hline \multicolumn{8}{|l|}{ Apidae } \\
\hline Bee & 7 & $\begin{array}{l}\text { Honey, } \\
\text { gel }\end{array}$ & Flu, cough, leg pain & $\begin{array}{l}\text { Respiratory tract diseases, } \\
\text { musculoskeletal and connective } \\
\text { tissue disorders }\end{array}$ & 0 & 0 & 0 \\
\hline \multicolumn{8}{|l|}{ Malacostraca } \\
\hline \multicolumn{8}{|l|}{ Ocypodidae } \\
\hline $\begin{array}{l}\text { Ocypode quadrata } \\
\text { (Fabricius, 1787)- } \\
\text { "caranguejo maria- } \\
\text { farinha," ghost } \\
\text { crab }\end{array}$ & 1 & $\begin{array}{l}\text { Whole } \\
\text { body }\end{array}$ & Asthma crisis & Respiratory tract diseases & 0 & 0 & 0 \\
\hline \multicolumn{8}{|l|}{ Hydrozoa } \\
\hline \multicolumn{8}{|l|}{ Physaliidae } \\
\hline $\begin{array}{l}\text { Physalia physalis } \\
\text { (Linnaeus, 1758)_- } \\
\text { "caravela- } \\
\text { portuguesa," } \\
\text { Portuguese man- } \\
\text { of-war }\end{array}$ & 1 & $\begin{array}{l}\text { Whole } \\
\text { body }\end{array}$ & Wounds & $\begin{array}{l}\text { External causes of morbidity and } \\
\text { mortality }\end{array}$ & 0 & 0 & 0 \\
\hline
\end{tabular}

turtle (17 citations), Cerdocyon thous (Linnaeus, 1758)fox (15 citations), and Gallus gallus (Linnaeus, 1758)chicken (11 citations). The significant number of citations of S. merianae confirms the importance of the species as a therapeutic resource in the study area. Its medicinal use has been registered in several localities of the country [54-59]. The data show a prevalence of wild species $(n=19)$ being used as therapeutic resources when compared with domestic species $(n=3)$, corroborating the results reported by Alves and Rosa [33] on the predominant use of wild species in the folk Brazilian medicine. This trend has been recorded in various medical systems around the world [24, 30, 60-63].

Regarding the relative importance of the species, although C. mydas (green turtle) was not the most cited by informants, it was the most used for a wide range of diseases, presenting an $\mathrm{RI}=1.6$. It was considered the most versatile species for multiple disease prescriptions, followed by sheep (O. aries), RI = 1.5; chicken (G. gallus), $\mathrm{IR}=1.1$; teju (S. merianae), $\mathrm{RI}=1.0$; and rattlesnake (Cortiles durissus Linnaeus, 1758), RI = 1.0 (Table 3).

Among the animals listed in this study, 14 are terrestrial, most of them from the dry forest environment. Additionally, the use of aquatic animal species from marine/estuarine habitats was also reported $(n=8)$. Among these, the species with the highest importance index (RI) was the green turtle C. mydas. The data suggest that human communities tend to use medicinal animals in accessible environments in local ecosystems. As pointed out by Alves and Rosa [23], the use of local resources that are more easily accessible is probably
Table 3 Relative importance of the most versatile medicinal animal species in the fishing community of Diogo Lopes - RN, Brazil

\begin{tabular}{lll}
\hline Species & Habitat & Relative importance \\
\hline Chelonia mydas & Aquatic & 1.6 \\
Ovis aries & Terrestrial & 1.5 \\
Gallus gallus & Terrestrial & 1.1 \\
Salvator merianae & Terrestrial & 1.0 \\
Crotalus durissus & Terrestrial & 1.0 \\
lguana iguana & Terrestrial & 0.8 \\
Cerdocyon thous & Terrestrial & 0.8 \\
Sotalia guianensis & Aquatic & 0.8 \\
Bee (Apidae) & Terrestrial & 0.5 \\
Boa constrictor & Terrestrial & 0.4 \\
Euphractus sexcinctus & Terrestrial & 0.4 \\
Tropidurus hispidus & Terrestrial & 0.3 \\
Echeneis naucrates & Aquatic & 0.2 \\
Ocypode quadrata & Aquatic & 0.2 \\
Hippocampus reidi & Aquatic & 0.2 \\
Physalia physalis & Aquatic & 0.2 \\
Rhinella jimi & Terrestrial & 0.2 \\
Rhizoprionodon lalandii & Aquatic & 0.2 \\
Mazama sp. & Terrestrial & 0.2 \\
Coragyps atratus & Terrestrial & 0.2 \\
Scomberomorus cavalla & Aquatic & 0.2 \\
Canis familiaris & Terrestrial & 0.2 \\
\hline & & \\
\hline
\end{tabular}


related to cultural and historical aspects. This is because medicinal knowledge is focused on species that locals are familiar with, reflecting the transmission of knowledge across generations as well as financial constraints that limit access and use of other resources. This relationship between medicinal use and local knowledge has been recorded in several studies in different parts of the world. Adeola [64] noted that in Nigeria, the use of wild animals is linked to the environment in which people live and the relative abundance of species in that environment. Similar situation was recorded in India $[24,65]$ and Argentina [14, 25]. In Brazil, studies carried out in fishing communities have documented the strong tendency of aquatic animals to be used in folk medicinal practices [23, 32, 33, 52, 66, 67]. On the other hand, studies developed in populations of semiarid regions indicate the prevalence of terrestrial or endemic animals from these regions [30, 34-36, 59].

From the total number of records, it was possible to identify 14 products from whole animals or parts of their bodies, which are used to treat 38 diseases diagnosed by the community (Table 2). As for the methods of preparation of these products, the following were recorded: whole animals or parts are generally roasted and macerated and the resulting powder is ingested in the form of teas. Animal metabolism secretions such as lard, gel, blood, and tallow are used as ointments to massage the affected area or ingested pure or with coffee. Among these zootherapeutic products cited by informants, lard stood out as one of the most commonly used products (number of citations $=120$ ), especially teju's lard $(S$. merianae) which was reported to be widely used to treat throat problems. Most informants $(78 \%)$ who cited the use of lard reported that it needs to be melted or heated and taken pure in the form of oil. When used externally, the lard is applied to the wound. According to Alves et al. [68], the frequency in which lard is used can be attributed to the fact that the main animals used are vertebrates, which have a large amount of fat in their body. Previous work has also reported the use of lard as the most commonly used raw material in the treatment and cure of various diseases $[47,50,69,70]$.

The categories of diseases with the highest number of citations were respiratory tract diseases (92 citations) and musculoskeletal system and connective tissue diseases ( 35 citations). The diseases with the highest number of citations were throat inflammation (54 citations) and sore throat (27 citations). This trend registered in the present study corroborates the pattern pointed out in other cities of the Northeast region, indicating that these categories are widely treated with medicinal animals [33, 58, 68, 71]. Additionally, according to the informants, it was possible to register the use of the same species in the treatment of more than one disease. An example was the ram $(O$. aries), whose parts (tallow and lard) are used to treat various illnesses such as bruise, arm twists, ankle fracture, leg pain, swelling, plantar fasciitis, joint pain, knee pain, cracking heels, bone pain, hard joints, and bent knee. Another animal of multiple medicinal uses in the study area is the turtle (C. mydas) which is used to treat throat inflammation, bone pain, stroke, back pain, rheumatism, boil, and thrombosis, being also used for healing. Other species have also been reported for various therapeutic indications: teju (S. merianae), chicken (G. gallus), chameleon (Iguana iguana Linnaeus, 1758), fox (C. thous), and rattlesnake (C. durissus).

The use of zootherapeutic products may be related to the use of resources that would otherwise be wasted [69]. According to these authors, populations tend to use leftovers of food for therapeutic purposes. Not surprisingly, therefore, several of the medicinal animals are hunted or fished by the local population for food purposes. An example is the teju (S. merianae), which represents an important source of protein and is one of the most hunted species used as food in traditional and/or indigenous communities [72], and its leftovers such as lard, tail, and tongue are used as medicines.

According to most informants, the use of animals listed as a medicinal resource was a common practice in the past and was most often obtained through hunting or given by older people (parents, grandparents, greatgrandparents, or hunter friends). When asked about the preference for treating a disease, they reported that they preferred the folk medicine (from animals or plants) to medicines sold in pharmacies, but it was currently very difficult to get the animal. As pointed out by Alves et al. [54], some factors contribute to the reduction of use of zootherapics and herbal medicines. Among them are the decline of fauna and flora due to deforestation, burning, and hunting, and the presence of health centers with free distribution of medicines. This reduction in the use of zootherapics was also reported by informants in the study by Lima and Santos [73], who recorded that the species were decreasing as a consequence of hunting and deforestation activities for development.

Among the medicinal species recorded in the present study, the seahorse (Hippocampus reidi Ginsburg, 1933), the turtle (C. mydas), and the dolphin (Sotalia guianensis (P.-J. van Bénéden, 1864)) are present in the Red List of Threatened Species of the International Union for Conservation of Nature (IUCN) [43] and the List of Endangered Brazilian Fauna Species [44]. The impacts of zootherapeutic practices on wild populations should be carefully investigated, since, unlike herbal remedies, the use of zootherapeutic products most often occurs after an animal is sacrificed [14]. However, it is important to point out that, despite being used in folk medicine, the 
impacts of zootherapeutic practice on threatened species are not significant, especially when compared with other factors triggering population decline such as habitat degradation and capture of these animals for other purposes that are not necessarily medicinal [74]. According to Alves et al. [75], understanding the trend and multiplicity of therapeutic use of animals is a particular concern from a conservationist point of view. This is noteworthy because threatened species such as those reported in this and other studies can be replaced by non-threatened species with similar properties.

Given the information obtained from the informants, it is noticeable that there is a tendency of using medicinal animals that occur near the sampled locality. This was especially clear in relation to species that are targeted for hunting and fishing, showing that the environment directly influences the choice of zootherapeutic resources and the medicinal use represents a strategy of optimizing the use of resources. Zootherapeutic practices are related to ecological, cultural, historical, sociological, economic, and health aspects [58, 76], connecting people to the environment and enriching local knowledge [77, 78].

\section{Acknowledgements}

We also would like to thank CNPq for the productivity grant awarded to RRNA and SFL. The authors thank the Brazilian Coordination for the Improvement of Higher Education Personnel (CAPES) for the scholarship granted to the first author.

They especially thank all the interviewees who shared their knowledge.

\section{Authors' contributions}

ISPB, AKMB, SFL, TLPD, and RRNA contributed to the writing of the manuscript, literature survey and interpretation, and analysis of taxonomic aspects; ISPB contributed to the ethnozoological data. All authors read and approved the final manuscript.

\section{Funding}

This study was supported in part by the Coordenação de Aperfeiçoamento de Pessoal de Nível Superior - Brasil (CAPES) and CNPq/Edital Universal program (422041/2018-1).

\section{Availability of data and materials}

All data generated or analyzed during this research are included in this published article.

\section{Ethics approval and consent to participate}

The research was approved by the Research Ethics Committee of the Hospital Universitário Lauro Wanderley (HULW) under the Certificate of Presentation for Ethical Consideration (CAAE) ( $N^{\circ}$. 2,244,394). All interviewers consent to participate.

\section{Consent for publication}

Not applicable.

\section{Competing interests}

The authors declare that they have no competing interests.
Received: 9 September 2019 Accepted: 25 October 2019

Published online: 27 November 2019

\section{References}

1. Albuquerque UP, Medeiros PM, Almeida ALS, Monteiro JM, Neto EMFL, Melo JG, et al. Medicinal plants of the caatinga (semi-arid) vegetation of NE Brazil: a quantitative approach. J Ethnopharmacol. 2007;114:325-54.

2. Alves RRN, Rosa IL. Biodiversity, traditional medicine and public health: where do they meet? J Ethnobiol Ethnomed. 2007;3:9.

3. Boakye MK. Influence of ethnicity on cultural use of pangolins in Ghana and its implications on their conservation. Ethnobio Conserv. 2018;7:1-18.

4. Hurrell JA, Puentes JP. Plant species and products of the traditional Chinese phytotherapy in the Ciudade Autónoma de Buenos Aires, Argentina. Ethnobio Conserv. 2017;6:1-43.

5. Latorre EC, Canavero A, Pochettino ML. Comparison of medicinal plant knowledge between rural and urban people living in the biosphere reserve "Bioma PampaQuebradas del Norte", Uruguay: an opportunity for biocultural conservation. Ethnobio Conserv. 2018;7:1-34.

6. Calixto JB. Twenty-five years of research on medicinal plants in Latin America: a personal view. J Ethnopharmacol. 2005;100:131-4.

7. Cunningham AB: An Africa-wide overview of medicinal plant harvesting, conservation and health care. Pages 116-129 in Bodeker G., Bhat K.K.S., J. B, P. V, eds. Medicinal plants for forest conservation and health care. Rome: Food \& Agriculture Organization of the UN (FAO); 1997.

8. Halberstein RA. Medicinal plants: historical and cross-cultural usage patterns. Ann Epidemiol. 2005;15:686-99.

9. Iwu MM. Handbook of African medicinal plants. Boca Raton: CRC; 1993.

10. Zank S, Hanazaki N. Healing faith: knowledge, learning and social relationships of healers from Araripe plateau, Brazil. Ethnobio Conserv. 2016; 5:1-15

11. Marques JGW. A fauna medicinal dos índios Kuna de San Blás (Panamá) e a hipótese da universalidade zooterápica. Vitória: 47a Reunião Anual da Sociedade Brasileira para o Progresso da Ciência; 1994. p. 324.

12. Alves RRN, Rosa IL. Animals in traditional folk medicine: implications for conservation, vol. 1. Berlin Heidelberg: Springer-Verlag; 2013.

13. Alves RRN, Policarpo IS. Animals and human health: where do they meet? In: RRN A, editor. Ethnozoology. Albuquerque: Elsevier; 2018. p. 233-59.

14. Castillo L, Ladio AH. Zootherapy and rural livestock farmers in semiarid Patagonia: the transfer of animal aptitudes for health. Ethnobio Conserv. 2019:8:1-23

15. Hajdari A, Pieroni A, Jhaveri M, Mustafa B, Quave C. Ethnomedical remedies among Slavic speaking people in South Kosovo. Ethnobio Conserv. 2018;7: $1-42$.

16. Van Vliet N, Moreno J, Gómez J, Zhou W, Fa JE, Golden C, et al. Bushmeat and human health: assessing the evidence in tropical and sub-tropical forests. Ethnobio Conserv. 2017;6:1-45.

17. Yinfeng $G$, Xueying $Z$, Yan C, Di W, Sung W. Sustainability of wildlife use in traditional Chinese medicine. In: Conserving China'Biodiversity: reports of the Biodiversity Working Group (BWG), China Council for International Cooperation on Environment and Development; 1997.

18. Alves RRN, Alves HN. The faunal drugstore: animal-based remedies used in traditional medicines in Latin America. J Ethnobiol Ethnomed. 2011;7:1-43.

19. Alves RRN, Vieira WLS, Santana GG, Vieira KS, PFGP M. Herpetofauna used in traditional folk medicine: conservation implications. In: RRN A, Rosa IL, editors. Animals in traditional folk medicine: implications for conservation. Berlin Heidelberg: Springer-Verlag; 2013. p. 109-33.

20. Alves RRN, Souto WMS, Barboza RRD, DMM B. Primates in traditional folk medicine: world overview. In: RRN A, Rosa IL, editors. Animals in traditional folk medicine: implications for conservation, vol. 1. Berlin: Springer; 2013. p. 135-70.

21. Alves RRN, Pinto LCL, Barboza RRD, Souto WMS, Oliveira REMCC, WLS V. A global overview of carnivores used in traditional medicines. In: RRN A, Rosa IL, editors. Animals in traditional folk medicine: implications for conservation, vol. 1. Berlin: Springer; 2013. p. 171-206.

22. Meyer-Rochow VB. Therapeutic arthropods and other, largely terrestrial, folkmedicinally important invertebrates: a comparative survey and review. J Ethnobiol Ethnomed. 2017;13:1-31.

23. Alves RRN, Rosa IL. From cnidarians to mammals: the use of animals as remedies in fishing communities in NE Brazil. J Ethnopharmacol. 2006;107: 259-76. 
24. Mahawar MM, Jaroli DP. Traditional zootherapeutic studies in India: a review. J Ethnobiol Ethnomed. 2008;4:17.

25. Martinez GJ. Use of fauna in the traditional medicine of native Toba (qom) from the Argentine Gran Chaco region: an ethnozoological and conservationist approach. Ethnobio Conserv. 2013;2:1-43.

26. Whiting MJ, Williams VL, Hibbitts TJ. Animals traded for traditional medicine at the Faraday market in South Africa: species diversity and conservation implications. In: RRN A, Rosa IL, editors. Animals in traditional folk medicine: implications for conservation. Berlin Heidelberg: Springer-Verlag; 2013. p. 421-73.

27. Altaf M, Umair M, Abbasi AR, Muhammad N, Abbasi AM. Ethnomedicinal applications of animal species by the local communities of Punjab, Pakistan. J Ethnobiol Ethnomed. 2018;14:1-25.

28. Jugli S, Chakravorty J, Meyer-Rochow VB. Zootherapeutic uses of animals and their parts: an important element of the traditional knowledge of the Tangsa and Wancho of eastern Arunachal Pradesh, North-East India. In: Environment, development and sustainability; 2019. p. 1-36.

29. Alves RRN, Rosa IL, Santana GG. The role of animal-derived remedies as complementary medicine in Brazil. BioScience. 2007;57:949-55.

30. Ferreira FS, Albuquerque UP, Coutinho HDM, Almeida WO, Alves RRN. The trade in medicinal animals in Northeastern Brazil. Evid Based Complement Alternat Med. 2012;2012:1-20.

31. Ferreira FS, Fernandes-Ferreira H, Leo Neto N, Brito SV, Alves RRN. The trade of medicinal animals in Brazil: current status and perspectives. Biodivers Conserv. 2013;22:839-70.

32. Andrade JN, Costa-Neto EM. Primeiro registro da utilização medicinal de recursos pesqueiros na cidade de São Félix, Estado da Bahia, Brasil. Acta Scientiarum Biological Sci. 2005;27:177-83.

33. Alves RRN, Rosa IL. Zootherapeutic practices among fishing communities in North and Northeast Brazil: a comparison. J Ethnopharmacol. 2007;111:82-103.

34. Alves RRN, Oliveira MGG, Barboza RRD, Singh R, Lopez LCS, RRN A, et al. Forsch Komplementmed/research in complementary medicine, vol. 16; 2009. p. 305-12.

35. Alves RRN, Oliveira MGG, Barboza RRD, Lopez LCS. An ethnozoological survey of medicinal animals commercialized in the markets of Campina Grande, NE Brazil. Hum Ecol Rev. 2010;17:11-7.

36. Alves RRN, Melo MF, Ferreira FS, Trovão DMBM, Dias TLP, Oliveira JV, et al. Healing with animals in a semiarid northeastern area of Brazil. Environ Dev Sustain. 2016;18:1733-47.

37. Phillips O, Gentry AH. The useful plants of Tambopata, Peru: I. statistical hypotheses tests with a new quantitative technique. Econ Bot. 1993;47:15-32

38. INMET. III Distrito de Meteorologia. Seção de Observação e Meteorologia Aplicada. Fornecimento de dados meteorológicos. In: Macau/RN. Recife: Estação 82594. Parâmetro. 203; 2000.

39. ECOPLAM. Relatório de Avaliação Ambiental - RAA dos Campos Petrolíferos de Conceição, Salina Cristal e Macau, vol. 1. Natal: Petrobras - E \& P - RN/ CE - ASSEMA; 1997.

40. Santos DAS. Mapeamento da área submersa da laguna de Diogo Lopes Barreiras (RN). Natal: Universidade Federal do Rio Grande do Norte; 2003.

41. Albuquerque UP, Lucena RFP, Alencar NL. Métodos e técnicas para coletas de dados etnobiológicos. In: Albuquerque UP, RFP L, LVFC C, editors. Métodos e técnicas na pesquisa etnobiológica e etnoecológica. Recife: Nuppea; 2010. p. 41-66.

42. Baldin N, Munhoz EMB. Snowball (bola de neve): uma técnica metodológica para pesquisa em educação ambiental comunitária. In: X Congresso Nacional de Educação. Curitiba: Educere; 2011.

43. IUCN. Red list of threatened species. Version 2018.1. www.iucnredlist.org. Accessed 15 Sept 2019.

44. MMA - Ministério do Meio Ambiente. Lista das Espécies da Fauna Brasileira Ameaçadas de Extinção. Brasília: Biodiversidade; 2014.

45. Bennett BC, Prance GT. Introduced plants in the indigenous pharmacopoeia of Northern South America. Econ Bot. 2000;54:90-102.

46. Policarpo IS, Barboza RRD, AKM B, RRN A. Mammalian fauna used in folk medicine among hunters in a semiarid region of Brazil. In: Environment, development and sustainability; 2018.

47. Silva MLV, Alves ÂGC, Almeida AV. A zooterapia no Recife (Pernambuco): uma articulação entre as práticas ea história. Biotemas. 2004;17:95-116.

48. Almeida CFCB, Albuquerque UP. Uso e conservação de plantas e animais medicinais no estado de Pernambuco (Nordeste do Brasil): um estudo de caso. Interciência. 2002;26:276-85.

49. Seixas CS, Begossi A. Ethnozoology of fishing communities from Iha Grande (Atlantic forest coast, Brazil). J Ethnobiol Ethnomed. 2001;21:107-35.
50. Costa Neto EM. "Barata é um santo remédio": introdução à zooterapia popular no estado da Bahia. Feira de Santana: UEFS; 1999.

51. Branch LC, Silva MF. Folk medicine of Alter do Chao, Para, Brazil. Acta Amazon. 1983;13:737-97.

52. Begossi A. Food taboos at Búzios Island (Brazil): their significance and relation to folk medicine. J Ethnobiol Ethnomed. 1992:12:117-39.

53. Alves RRN, Feijó A, Barboza RRD, Souto WMS, Fernandes-Ferreira $H$, Cordeiro-Estrela P, et al. Game mammals of the Caatinga biome. Ethnobio Conserv. 2016:5:1-51.

54. Alves RRN, Soares TC, Mourão JS. Uso de animais medicinais na comunidade de Bom Sucesso, Soledade, Estado da Paraíba, Brasil. Sitientibus Série Ciências Biológicas. 2008:8:142-7.

55. Silva NLG, Ferreira FS, Coutinho HDM, RRN A. Zooterápicos utilizados em Comunidades rurais do município de Sumé, Paraíba, Nordeste do Brasil. In: Costa Neto EM, RRN A, editors. Zooterapia - Os animais na medicina popular Brasileira. Recife: Nuppea; 2010. p. 245-67.

56. Alves RRN, Barbosa JAA, Santos SLDX, Souto WMS, Barboza RRD. Animal-based remedies as complementary medicines in the semi-arid region of Northeastern Brazil. Evid Based Complement Alternat Med. 2011;2011:179876.

57. Alves RRN, Neta ROS, Trovão DMBM, Barbosa JEL, Barros AT, Dias TLP. Traditional uses of medicinal animals in the semi-arid region of northeastern Brazil. J Ethnobiol Ethnomed. 2012;8:1-7.

58. Ferreira FS, Brito SV, Costa JGM, Alves R, Coutinho HDM, Almeida WO. Is the body fat of the lizard Tupinambis merianae effective against bacterial infections? J Ethnopharmacol. 2009;126:233-7.

59. Oliveira ES, Torres DF, Brooks SE, Alves RRN. The medicinal animal markets in the metropolitan region of Natal City, northeastern Brazil. J Ethnopharmacol. 2010;130:54-60.

60. Alonso-Castro AJ. Use of medicinal fauna in Mexican traditional medicine. J Ethnopharmacol. 2014;152:53-70.

61. Alves RRN, Souto WMS, Barboza RRD. Primates in traditional folk medicine: a world overview. Mammal Rev. 2010:40:155-80.

62. Ceríaco LMP. A review of fauna used in zootherapeutic remedies in Portugal: historical origins, current uses, and implications for conservation. In: Alves RRN, Rosa IL, editors. Animals in traditional folk medicine. BerlinHeidelberg: Springer-Verlag; 2013. p. 317-45.

63. El-Kamali HH. Folk medicinal use of some animal products in Central Sudan. J Ethnopharmacol. 2000;72:279-82.

64. Adeola MO. Importance of wild animals and their parts in the culture' religious festivals, and traditional medicine, of Nigeria. Environ Conserv. 1992;19:125-34

65. Chakravorty J, Meyer-Rochow V, Sampat G. Vertebrates used for medicinal purposes by members of the Nyishi and Galo tribes in Arunachal Pradesh (North-East India). J Ethnobiol Ethnomed. 2011;7:13.

66. Begossi A, Braga FMS. Food taboos and folk medicine among fishermen from the Tocantins River. Amazoniana. 1992;12:101-18.

67. Costa-Neto EM, Marques JGW. Faunistic resources used as medicines by artisanal fishermen from Siribinha Beach, State of Bahia, Brazil. J Ethnobiol Ethnomed. 2000;20:93-109.

68. Alves RRN, Lima HN, Tavares MC, Souto WMS, Barboza RRD, Vasconcellos A. Animal-based remedies as complementary medicines in Santa Cruz do Capibaribe, Brazil. In: BMC complementary and alternative medicine; 2008.

69. Moura FBP, Marques JGW. Zooterapia popular na Chapada Diamantina: uma medicina incidental. Cien Saude Colet. 2008;13:2179-88.

70. Hanazaki N, Alves RRN, Begossi A. Hunting and use of terrestrial fauna used by Caiçaras from the Atlantic Forest coast (Brazil). J Ethnobiol Ethnomed. 2009;5:1-8.

71. Alves RRN. Fauna used in popular medicine in Northeast Brazil. J Ethnobiol Ethnomed. 2009;5:1-30.

72. Saadoun A, Cabrera MC. A review of the nutritional content and technological parameters of indigenous sources of meat in South America. Meat Sci. 2008:80:570-81.

73. Lima JRB, Santos CAB. Recursos animais utilizados na medicina tradicional dos índios pankararu no Nordeste do Estado, Pernambuco, Brasil. Etnobiologia. 2010;8:39-50.

74. Alves RRN, Dias TLP. Usos de invertebrados na medicina popular no Brasil e suas implicações para conservação. Trop Conserv Sci. 2010;3:159-74.

75. Alves RRN, Oliveira TPR, Medeiros MFT. Trends in medicinal uses of edible wild vertebrates in Brazil. Evid Based Complement Alternat Med. 2017;2017: 4901329.

76. Lev E. Ethno-diversity within current ethno-pharmacology as part of Israeli traditional medicine - a review. J Ethnobiol Ethnomed. 2006;2:4. 
77. Alves RRN, Rosa IL. Why study the use of animal products in traditional medicines? J Ethnobiol Ethnomed. 2005;1:1-5.

78. Janssen J, Gomez L. Common Sun Skink Eutropis multifasciata (Kuhl 1820) sold for Traditional Medicine in Indonesia and potential conservation implications. Ethnobio Conserv. 2019;8:1-8.

\section{Publisher's Note}

Springer Nature remains neutral with regard to jurisdictional claims in published maps and institutional affiliations.

Ready to submit your research? Choose BMC and benefit from:

- fast, convenient online submission

- thorough peer review by experienced researchers in your field

- rapid publication on acceptance

- support for research data, including large and complex data types

- gold Open Access which fosters wider collaboration and increased citations

- maximum visibility for your research: over $100 \mathrm{M}$ website views per year

At $\mathrm{BMC}$, research is always in progress.

Learn more biomedcentral.com/submissions 